\title{
Fibrous Dysplasia in Maxillary Bone: Case Report
}

\section{Marcelo Domingues Pinto', Gustavo Gaffrée Braz', Roberto Gomes Santos ${ }^{3}$, Diego Polido ${ }^{4}$, Jonathan Rodopiano Paixão ${ }^{1}$, Hugo Solé de Melo ${ }^{1}$ and Roberto Almeida Elias ${ }^{5}$}

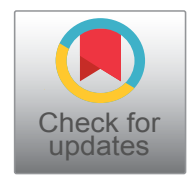

\begin{abstract}
${ }^{1}$ Department of Maxillofacial, Resident of the Hospital Municipal Lourenço Jorge, University Grande Rio, Brazil
${ }^{2}$ Department of Maxillofacial, Chief Director of Surgery Hospital Municipal Lourenço Jorge, Rio de Janeiro State University, Brazil ${ }^{3}$ Department of Maxillofacial, Chief of Maxillofacial Service Hospital Municipal Lourenço Jorge, University Gama Filho, Brazil ${ }^{4}$ Department of Maxillofacial, Resident of the Hospital Municipal Lourenço Jorge, University Nova Iguaçu, Brazil ${ }^{5}$ Specialist in Maxilofacial by the State University of Rio de Janeiro, Brazil
\end{abstract}

*Corresponding author: Marcelo Domingues Pinto, Department of Maxillofacial, Resident of the Hospital Municipal Lourenço Jorge, University Grande Rio, Brazil

\begin{abstract}
Fibrous dysplasia is a benign lesion, congenital, recurrent character and etiology unknown, caused by a bone modeling disorder with constant alterations of the normal bone being replaced by immature fibrous tissue. The lesion may involve one or more bones being the maxilla the facial bone more affected. We report a case of polyostotic fibrous dysplasia in a male patient complaining of increased volume in the right genital region. In this case, Computed Tomography (CT) was the main radiographic examination to demonstrate the extension and radiodensity that the lesion assumes in the craniofacial bones, being therefore of fundamental importance in the surgical planning and in the longitudinal follow-up of the operated patient. The diagnosis was confirmed by anatopathology and the treatment of choice was osteoplasty. This article also aims to review the main clinical, radiological, histopathological, differential diagnosis and Fibrous dysplasia treatment.
\end{abstract}

\section{Keywords}

Polyostotic maxillary fibrous dysplasia, Fibrous lesions

\section{Introduction}

Fibrous Dysplasia (FD) is described as a slowly evolving, benign tumour disorder of bone development characterized by the replacement of normal bone by excessive proliferation of cellular fibrous connective tissue interspersed with irregular bone trabeculae [1,2].

In 1891, Von Recklinghausen denominated de "generalist fibrous osteitis" pathological conditions that characterized deformities and bone alterations $[3,4]$. Therefore, only in 1938, Liechtenstein and Jaffe recognized these conditions described, previously, as a well-characterized disease and named it fibrous dysplasia $[5,6]$.

The etiology of this entity is still unknown $[7,8]$. Clinically it is classified as monostotic or polyostotic, the first being focal, limited to a single bone, and the second, multifocal, involving several bones simultaneously [9].

The monostotic form shows no predilection for sex and is found in about $70 \%$ of all cases of fibrous dysplasia, with gnathic bones being the most commonly affected sites [10]. The cases of monostotic fibrous dysplasia are usually diagnosed during the second decade of life, with painless swelling being the most common feature $[1,2]$.

Polyostotic fibrous dysplasia is an uncommon condition, presenting a higher prevalence for females. The number of bones affected ranges from a few up to $75 \%$ of the entire skeleton and almost all patients with polyostotic fibrous dysplasia present craniofacial involvement with surprising predilection on one side of the body [11]. The involvement of two or more bones associated with brown-to-white pigmentation characterizes Jaffe-Lichtenstein Syndrome.

Clinically it presents the following characteristics: volume increase of slow growth with bulging of the involved region and facial asymmetry (when in great proportions) [12-14]. The soft tissue covering the lesion is normal in appearance [12-14]. Pain and paresthesia are rare complaints, with slow growth of the lesion, and the patient often cannot remember when the lesion was initially perceived [14]. 
It can be evaluated by conventional radiography, scintigraphy, magnetic resonance imaging and Computed Tomography Scans (CT) $[5,15]$ although CT is considered the exam of choice in the evaluation of craniofacial lesions [7].

Currently, the surgical treatment of resection or osteoplasty with cosmetic recontouring is recommended when there is functional or aesthetic impairment caused by the lesion, however it should be postponed as much as possible due to the possibility of recurrence in cases where bone growth is active $[7,16]$.

Thus, the present study aims to report a case of polyostotic bone dysplasia, as well as the clinical, imaging, laboratory, histological and development of the case aspects will be discussed.

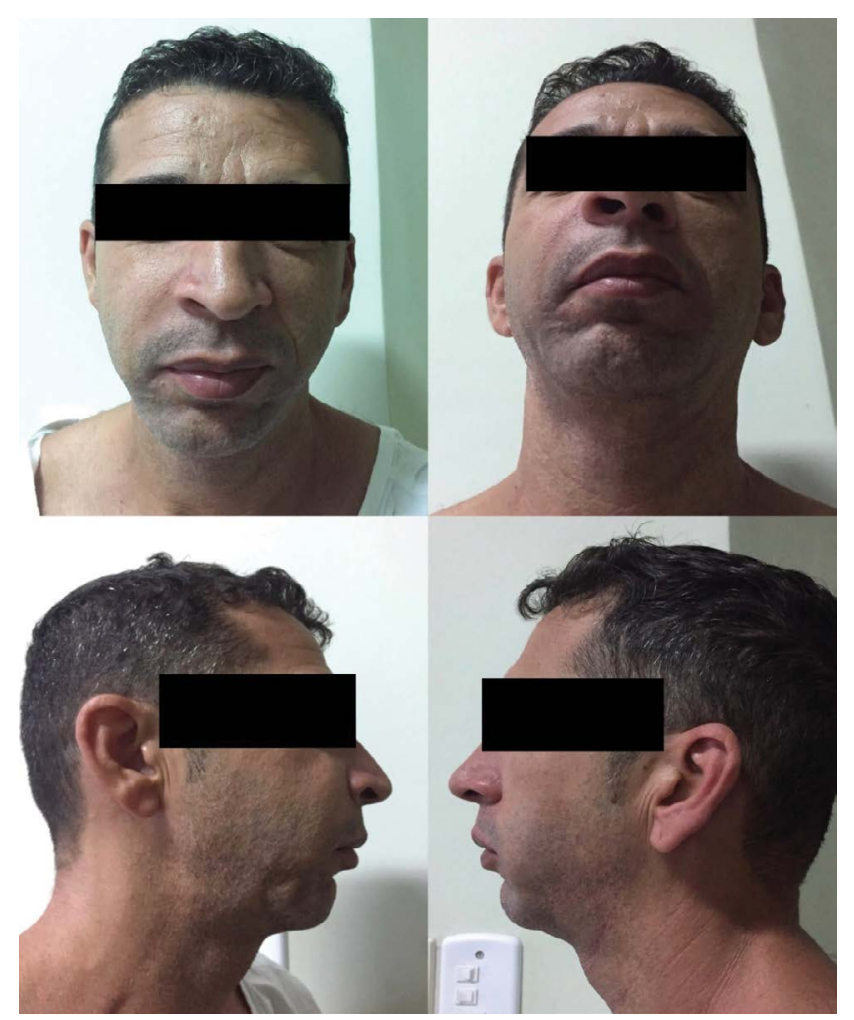

Figure 1: Facial asymmetry with nasal midline weaning and deletion in the nasogenian sulcus.

\section{Case Report}

Patient A.S.G, male, 43-years-old, leucoderma, looked for the service of surgery and bucomaxillofacial traumatology of Hospital Municipal Lourenço Jorge (HML), Rio de Janeiro, complaining of increased volume in the right genio region and wanted to improve its aesthetic picture.

In the anamnesis the patient reported that, despite having noticed such an alteration ten years ago, never sought treatment due to the absence of symptomatology, the same referred to no previous trauma. At the extra-oral clinical examination, in an inferior-superior view, facial asymmetry was observed, presenting a volumetric increase in the zygomatic region, right maxilla, deletion of the right nasogenian sulcus, no alteration of skin color, lymphadenopathy or any other alteration (Figure 1).

At the intraoral examination, there was an increase in volume in the region of end of sulcus from the canine to right maxillary tuberosity, with erasure of the vestibular sulcus. Of hard consistency to the palpation, with oral mucosa of normal appearance, smooth surface, regular and without ulcerations (Figure 2).

Computed tomography revealed a hyperdense image, an expansive mass in the maxilla palate and with compression of the right nasal cavity.

Face $\mathrm{CT}$ revealed an insufflating lesion, with dense glass density in the maxillary bone, partially occupying the right maxillary sinus and the ipsilateral nasal cavity and lowering of the hard palate with involvement of the dental alveoli (Figure 3). 3D reconstruction offers a better three-dimensional understanding of the lesion, being more accurate in relation to the volume, density and involvement of adjacent anatomical structures, which facilitates the treatment plan (Figure 4).

Patient referred to the surgical center of the Hospital Municipal Lourenço Jorge (HMLJ), Rio de Janeiro, submitted to a surgical procedure under general anesthesia, incision was made in the upper vestibule

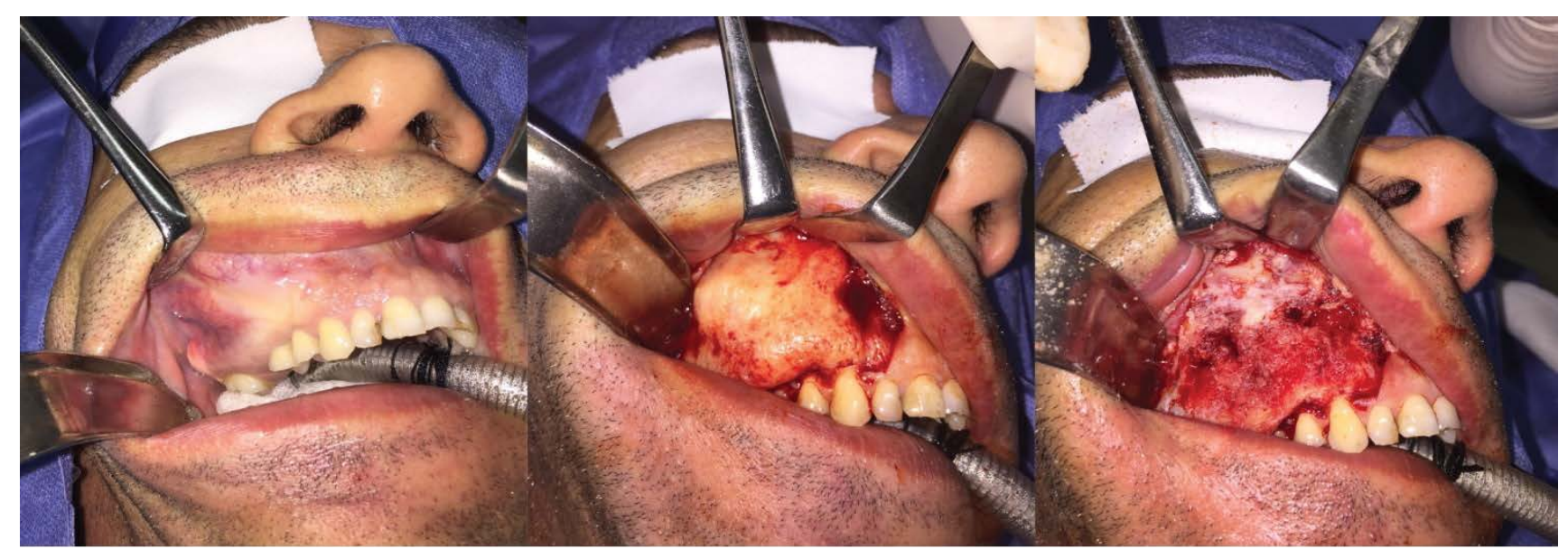

Figure 2: Intraoral followed by vestibule fund access for lesion exposure and osteoplasty. 
fundus, exposure of the lesion, partial resection of the lesion, and osteoplasty for correction of bone spikes with spherical drill (Figure 2).

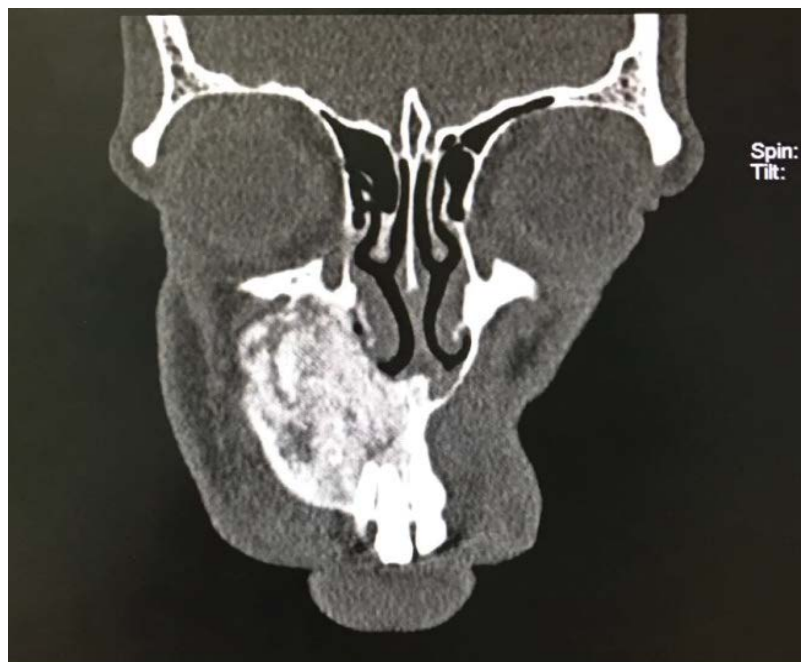

Figure 3: Selected coronal section for analysis.
Macroscopically we can see a spongy, yellowishlooking bone lesion. All material was collected and sent to the pathology center of the Universidade Estadual do Estado do Rio de Janeiro (UERJ), for histopathological analysis, which confirmed the diagnosis of fibrous dysplasia (Figure 5).

Patient referred for post-anesthetic recovery under anesthesiologist care, evolving postoperative without intercurrence.

At the moment the patient is with a year and a half of postoperative follow-up without clinical signs and satisfactory aesthetic result (Figure 6).

\section{Discussion}

The fibrous dysplasia is a uncommon disease, congenital, benign, characterized by defective bone modeling, with gradual replacement of normal bone by fibrosis with irregularly mineralized osteoids. Some believe to be a congenital anomaly of mesenchymal tissue development [17].

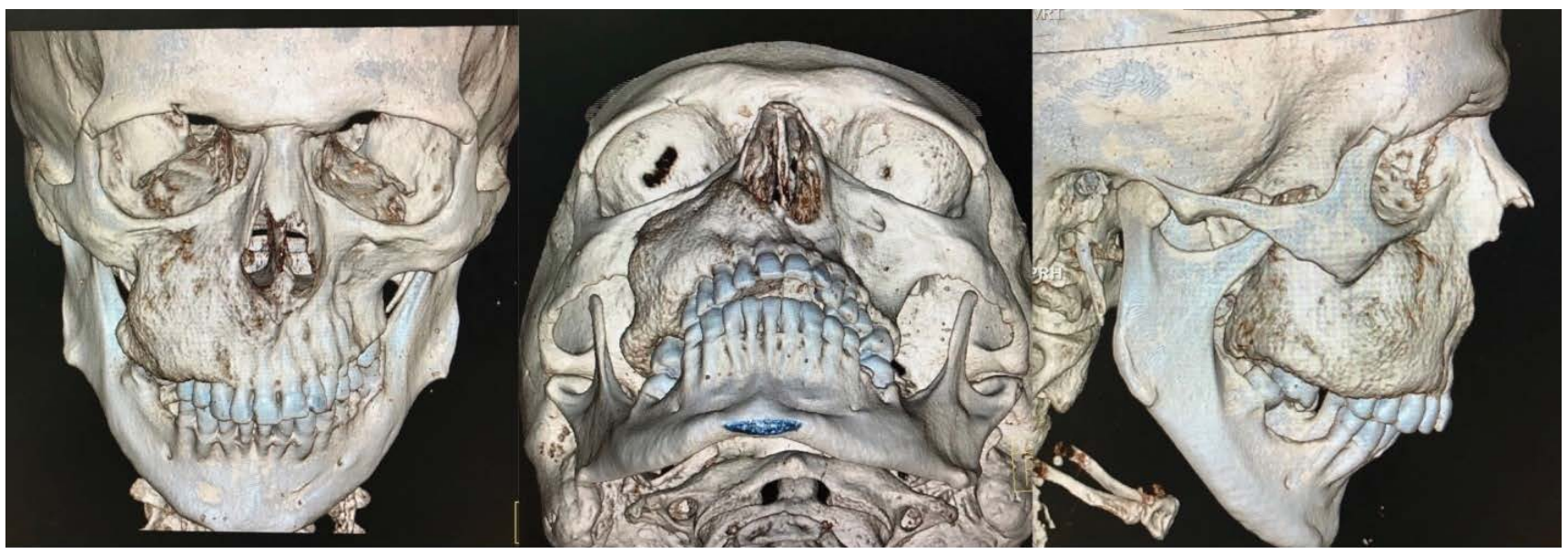

Figure 4: 3D computed tomography for better three-dimensional comprehension.

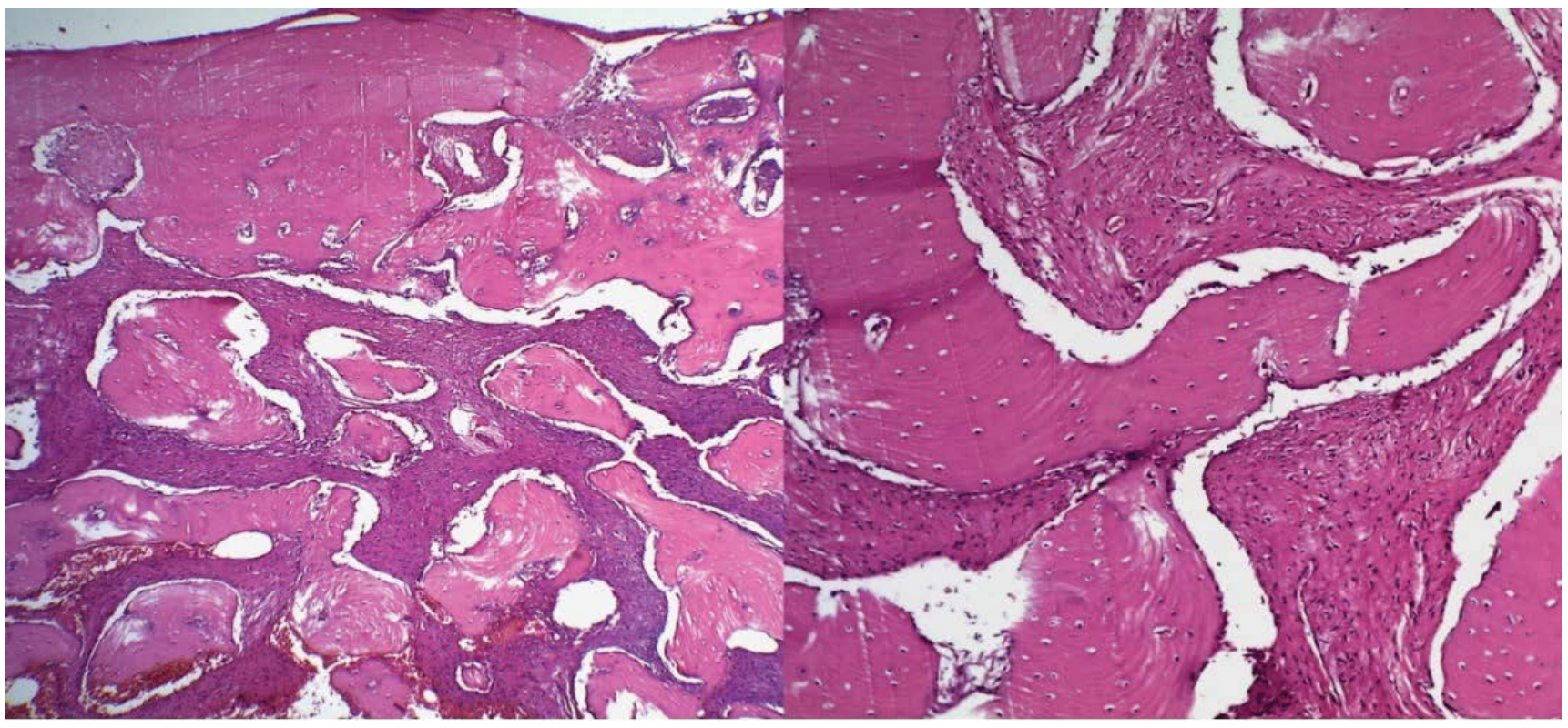

Figure 5: Anatomopathological. 


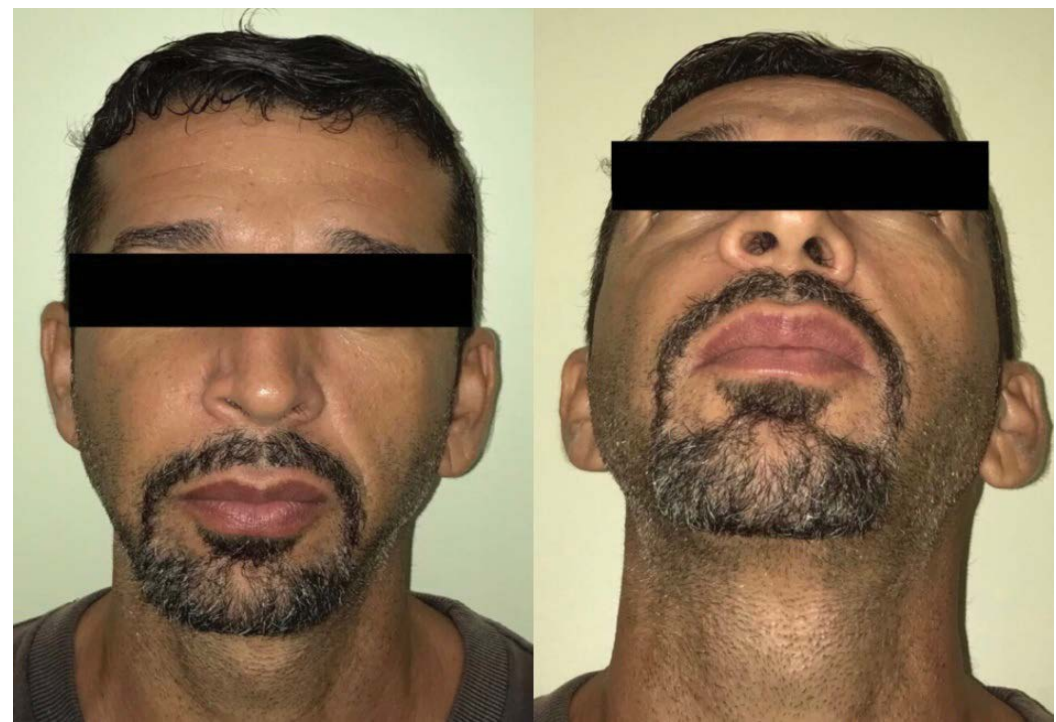

Figure 6: Satisfactory aesthetics, enhanced symmetry and absence of scarring.

The fibrous dysplasia is a pathology responsible for about $2.5 \%$ of bone tumours, and more than $7 \%$ of all non-malignant bone tumours $[4,18]$. In yours variety forms, affects one in every 4,000 to 10,000 individuals, don't having relation with hereditary factor [1].

Approximately $70 \%$ of the cases are manifested in the first decade of life, with slow growth, stabilizes at puberty, along with the skeleton. It's more frequent in females, recurrent in about $37 \%$ of the cases in adults [17].

Fibrous dysplasia remained with your indefinite etiology, with authors [14,19-21], describing embryological, neurological and congenital theories to explain their etiology. We now know that fibrous dysplasia is a sporadic condition that results from a post zygomatic mutation in the GNAS1 gene (protein bound to the guanine nucleotide $\alpha$-stimulating activity of polypeptide 1) [13]. We can affirm that fibrous dysplasia is a pathology that causes a disorganization in the bone tissue, generating an exaggerated and disorganized growth of this disease.

It's classified according to the number of bones affected and the presence or not of extra-skeletal abnormalities. The monostotic form affects only one bone and corresponds to $70-80 \%$ of FD cases. The polyostotic form, in which multiple bones are affected, can be divided in three subtypes: Craniofacial, in which only bones of the craniofacial are involved including the mandible and maxilla; Lichtenstein-Jaffe, in which besides the involvement of multiple bones of the skeleton are brown-to-brown pigmentations in the skin; Albright syndrome, characterized by the involvement of several bones, brown-to-brown pigmentation on the skin and endocrine impairment, with prominence for early puberty in girls. The polyostotic form responds for $20-30 \%$ of the cases [22]. Referring to tomographic examinations of the presented case, it was evidenced compromise of the palatine bones, maxilla, zygomatic complex right side, sphenoid, as well as region of nasal cavity.

Initially the disease is asymptomatic. The signs and symptoms in FD are dependent on the location of the lesion(s) and the compressive effect on neighboring structures as the tumour progresses slowly: Asymmetry and facial deformity; Pathological fractures; Obstruction of the paranasal sinuses generating recurrent infections, cysts and mucoceles; Anosmia, headache, loss of visual acuity by compression of the optic nerve; Alteration of ocular movements, ptosis, exophthalmos, strabismus; Conductive hearing loss [18,23-25].

The clinical signs and symptoms observed in this case were also found by several authors $[13,14,20,26$ 28], such as: Volume increase in the region, functional impairment, facial asymmetry, slow and asymptomatic evolution, mucosa adjacent to lesion without changes, hard consistency on palpation, normal-appearing mucosa with smooth surface and no ulcerations. The main symptoms reported by patients, when present, are: Throbbing or discomfort, some heat at the local of injury, diplopia, decreased visual acuity and may even lead to vision loss, deafness, nasal obstruction and dizziness $[18,29]$. Another very common feature of facial asymmetry is leontiasis ossea, caused by the expansion of maxilla, with loss of the nasomaxillary angle, generating a feline facial appearance [5]. In the report, the patient only complained about localized asymmetry, especially in the zygomatic-maxillary region.

CT is the test of choice for the study of lesion(s), avaliation of its extension and surgical preparation $[24,30]$. Basically, three radiographic patterns in the fibrous dysplasia of the skull and facial bones are described: Pategoid, alternating radiodense and radiotransparent areas; Sclerotic, homogeneously dense; and cystic pattern with spherical or ovoid radiolucent area surrounded by dense boundaries 
[25]. In the case reported, tomographic images of the lesion assumed a hyperdense pattern interspersed with hypodense areas of imprecise limits, resulting in the classic aspect of "ground glass". The definitive diagnosis of FD is made by the correlation of clinical, radiological and anatomopathological findings [31]. It is of great importance that computed tomography should always be used before the surgical procedure to evaluate the actual size of the pathology, anatomical structures and their compromise, and mainly, to guide in the planning of the extent of ostectomy and osteoplasty that will be performed. Besides that, can be divided into three patterns of involvement: the sclera, the cystic or the mixed [11].

The differential diagnosis includes benign lesions: Solitary unilocular cyst, non-ossifying fibroma, eosinophilic granuloma, cholesteatoma, meningioma, Paget's disease, osteochondroma, ossifying fibroma, giant cell reparative granuloma, exostoses, aneurysmal bone cyst, cystic fibrous osteitis; and malignancies, such as: Sarcoma and metastatic osteoblastic lesions [22]. The clinical aspects, in the case reported, along with the laboratory and imaging findings, were fibrosis dysplasia, but it is indispensable to perform histopathological examination to confirm the diagnosis.

Treatment is still debatable, especially in relation to lesions in the middle third of the face, which are difficult to access, when, after surgical intervention, esthetic and functional deficits can be found. Therefore, the best choice for approach in this region is through partial resection or bone remodeling. Aggressive surgeries are reserved for other cases in which vision or dentition is impaired [32]. The patient of the exposed clinical case had an important impairment of the right third of the face on the right side, but without nasal obstruction or malocclusion and with preserved visual acuity. The proposed surgery was to perform an intraoral access in the upper vestibule, with aesthetic purpose, and the high rate of recurrence of the lesion. The option was made for facial remodeling through osteoplasty, agreeing with the authors previously mentioned.

At anatomopathological examination, two forms can be distinguished macroscopically: The compact form, characterized by the presence of osteoid tissue, which progressively ossifies and assumes the appearance of mature bone and the cystic form, which presents one or more cavities surrounded by the changes described above.

Microscopically, the appearance of these two forms is unique. There is proliferation of fibrous tissue, with progressive ossification and destruction of the affected bone [18].

A specimen was sent for histopathological examination for microscopic examination of the lesion and confirmation of the diagnosis hypothesis. The microscopic findings of the lesions resemble those described in the literature $[13,33,34]$ and were: Young trabeculae interspersed by fibrous conjunctive tissue compatible with diagnosis of fibrous dysplasia.

Radiotherapy is contraindicated due to the possibility of malignant transformation of the post-irradiation lesion $[9,13,35]$, chemotherapy is also contraindicated, since it is not effective in curing the disease $[13,14,26]$.

Some authors defend the need for a clinical, endocrinological and scintigraphic study with computed tomography in patients diagnosed with fibrous dysplasia in search of other lesions in other sites and extra-skeletal involvement [24,30].

Clinical and radiological follow-up by CT is fundamental in patients with FD due to the moderate rate of recurrence of the lesion(s), and may reach $37 \%$ according to some authors [18].

\section{Conclusion}

Facing the clinical case, FD is considered a pathology, which may present functional and aesthetic impairment. In the moment of decision to treat fibrous dysplasia, consideration should be given to the patient's age, presence or absence of facial asymmetry, facial involvement and future rehabilitation. Because it is a tumour with no precise and relapsing limits, it is important to remove as much tissue as possible without causing mutilations to the patient, functional deficits or lesions of noble structures. Surgical treatment is indicated in case of significant deformity, significant pain or pathological fracture. Radiation therapy is contraindicated due to the high risk of sarcomatous transformation. The follow-up is of fundamental importance (time) in order to detect relapses or a possible, malignant change at an early stage.

\section{References}

1. Costanzi MA, Velasco e Cruz AA (2007) Envolvimento orbitário difuso por displasia fibrosa na síndrome de mccune albright: Relato de caso. Arq Bras Oftalmol 70: 1021-1023.

2. Neville BW, Damm DD, Allen CM, Bouquot JR (2004) Patologia Oral \& Maxilofacial. ( $2^{\text {nd }}$ edn), Rio de Janeiro: Guanabara Koogan.

3. Goisis M, Biglioli F, Guareschi M, Frigerio A, Mortini P (2006) Fibrous dysplasia of the orbital region: Current clinical perspectives in ophthalmology and craniomaxillofacial surgery. Ophthalmic Plast Reconst Surg 22: 383-387.

4. Ricalde P, Horswell BB (2001) Craniofacial fibrous dysplasia of the fronto-orbital region: $A$ case series and literature review. J Oral Maxillofac Surg 59: 157-167.

5. Lisle DA, Monsour PA, Maskiell CD (2008) Imaging of craniofacial fibrous dysplasia. J Med Imaging Radiat Oncol 52: $325-332$

6. Lustig LR, Holliday MJ, McCarthy EF, Nager GT (2001) Fibrous dysplasia involving the skull base and temporal bone. Arch Otolaryngol Head Neck Surg 127: 1239-1247.

7. Albuquerque MAP, Hirota SK, Maurício AR, Sugaya NN, 
Nunes FD, et al. (2006) Aspectos clínicos, patológicos e imaginológicos de um caso de displasia fibrosa. Rev Assoc Paul Cir Dent 60: 219-222.

8. Miloro M, Ghali GE, Larsen PE, Waite PD (2008) Princípios de Cirurgia Bucomaxilofacial. ( $2^{\text {nd }}$ edn), São Paulo: Santos.

9. Simon E, Matee M, Shubi F, Mselle T (1999) Cranio-facia fibrous dysplasia in a 38-year-old African woman: A case history. Oral Dis 5: 247-249.

10. Saueressig F, Oliveira MG (2004) Displasia fibrosa poliostótica associada à síndrome de Mmccune-albright: Relato de caso. Rev Bras Patol Oral 3: 70-76.

11. Botelho RA, Tornin OS, Yamashiro I, Menezes MC, Furlan S, et al. (2006) Características tomográficas da displasia fibrosa craniofacial: Estudo retrospectivo de 14 casos. Radiol Bras 39: 269-272.

12. Sentürk M, Külahli I, Emiroğlu A (2003) Fibrous dysplasia in the head and neck region: A report of three cases. Kulak Burun Bogaz Ihtis Derg 11: 25-28.

13. Waldron CA (2004) Doenças do osso. In: Neville BW, Damm DD, Allen CM, Bouquot JE, Patologia oral \& maxilofacial. Rio de Janeiro: Guanabara Koogan, 530-542.

14. Shafer WG, Hine MK, Levy BM (1987) Doenças dos ossos e das articulações. In: Shafer WG, Hine MK, Levy BM, Tratado de Patologia Bucal. Rio de Janeiro: Guanabara Koogan.

15. Mac Donald-Jankowski DS (2004) Fibro-osseous lesions of the face and jaws. Clin Radiol 59: 11-25.

16. Caridad JJM, Platas Jr F (2008) Fibrous dysplasia of the mandible: Surgical treatment with platelet-rich plasma and a corticocancellous iliac crest graft-report of a case. Oral Surg Oral Med Oral Pathol Oral Radiol Endod 105: 12-18.

17. Jan M, Dweik A, Destrieux C, Djebbari Y (1994) Fronto-orbital sphenoidal fibrous dysplasia. Neurosurgery 34: 544-547.

18. Alves AL, Canavarros F, Vilela DSA, Granato L, Próspero JD (2002) Displasia fibrosa: Relato de três casos. Rev Bras Otorrinolaringol 68: 288-292.

19. Akintoye SO, Otis LL, Atkinson JC, Brahim J, Kushner H, et al. (2004) Analyses of variable panoramic radiographic characteristics of maxillo-mandibular fibrous dysplasia in Mccune-albright syndrome. Oral Dis 10: 36-43.

20. Chen YR, Wong FH, Hsueh C, Lo LJ (2002) Computed tomography characteristics of non-syndromic craniofacial fibrous dysplasia. Chang Gung Med J 25: 1-8.

21. Onitsuka T, Kumagami H (1994) Sex hormones in fibrous dysplasia of the facial bone: An immunohistological study. Nihon Jibiinkoka Gakkai Kaiho 97: 2072-2074.
22. Pontual ML, Tuji FM, Yoo HJ, Bóscolo FN, Almeida SM (2004) Estudo epidemiológico da displasia fibrosa dos maxilares numa amostra da população brasileira. Odontol Clin Científ 3: 25-30.

23. Altuna X, Gorostiaga F, Algaba J (2004) Displasia fibrosa monostótica de seno frontal. A propósito de um caso. ORLDIPS 31: 84-87.

24. Fuster MA, Martín JÁ, Rodríguez-Pereira C, Navarro JM, Molina JV (2002) Displasia fibrosa monostótica de seno frontal con extensión orbitária. Acta Otorrinolaringol Esp 53: 203-206.

25. Oliveira RB, Granato L, Korn GP, Marcon MA, Cunha AP (2004) Displasia fibrosa do osso temporal: Relato de dois casos. Rev Bras Otorrinol 70: 695-700.

26. Stewart JCB (1989) Tumores benignos não odontogênicos. In: Regezi JA, Sciubba JJ, Patologiabucal: correlações clinico patológicas. Rio de Janeiro: Guanabara Koogan.

27. Yasuoka T, Takagi N, Hatakeyama D, Yokoyama K (2003) Fibrous dysplasia in the maxilla: Possible mechanism of bone remodeling by calcitonin treatment. Oral Oncol 39: 301-305.

28. Espinosa JM, Elizalde A, Aquerreta JD, Alcalde J, Zubieta JL (1998) Fibrous dysplasia of the maxilla. Ann Otol Rhinol Laryngol 107: 175-177.

29. Gosain AK, Celik NK, Aydin MA (2004) Fibrous dysplasia of the face: Utility of three-dimensional modeling and ex situ malar recontouring. J Craniofac Surg 15: 909-915.

30. Moreno BA, Sànchez AL, Collado JA, Garcia AU, Cortês JM, et al. (2007) Displasia fibrosa monostótica de seno esfenoidal. O.R.L. Aragon 10: 12-15.

31. Infante VP, Goldman RS, Rapoport A (2005) Displasia fibrosa do seio maxilar: Relato de um caso. Rev Bras Cirur Cab Pesc 34: 47-48.

32. Yetiser S, Gonul E, Tosun F, Tasar M, Hidir Y (2006) Monostotic craniofacial fibrous dysplasia: The Turkish experience. J Craniofac Surg 17: 62-67.

33. Erdem LO, Erdem CZ, Kargi S (2003) A case of monostotic fibrous dysplasia of the maxillary sinus. Kulak Burun Bogaz Ihtis Derg 10: 208-211.

34. Tsai TL, Ho CY, Guo YC, Chen W, Lin CZ (2003) Fibrous dysplasia of the ethmoid sinus. J Chin Med Assoc 66: 131133.

35. Campanacci M, Bertoni F, Capanna R (1979) Malignant degeneration in fibrous dysplasia (presentation of 6 cases and review of the literature). Ital J Orthop Traumatol 5: 373-381. 